\title{
Prevalence of plasmid-bearing and plasmid-free Chlamydia trachomatis infection among women who visited obstetrics and gynecology clinics in Malaysia
}

Tee Cian Yeow ${ }^{1}$, Won Fen Wong ${ }^{1 *}$, Negar Shafiei Sabet ${ }^{1,2}$, Sofiah Sulaiman ${ }^{3}$, Fatemeh Shahhosseini ${ }^{1}$, Grace Min Yi Tan', Elaheh Movahed', Chung Yeng Looi ${ }^{4}$, Esaki M. Shankar ${ }^{1}$, Rishien Gupta ${ }^{5}$,

Bernard P. Arulanandam ${ }^{5}$, Jamiyah Hassan ${ }^{3}$ and Sazaly Abu Bakar ${ }^{1}$

\begin{abstract}
Background: The $7.5 \mathrm{~kb}$ cryptic plasmid of Chlamydia trachomatis has been shown to be a virulence factor in animal models, but its significance in humans still remains unknown. The aim of this study was to investigate the prevalence and potential involvement of the C. trachomatis cryptic plasmid in causing various clinical manifestations; including infertility, reproductive tract disintegrity, menstrual disorder, and polycystic ovarian syndrome (PCOS) among genital C. trachomatis-infected patients.

Results: A total of 180 female patients of child bearing age (mean 30.9 years old, IQR:27-35) with gynecological complications and subfertility issues, who visited Obstetrics and Gynecology clinics in Kuala Lumpur, Malaysia were recruited for the study. Prevalence of genital chlamydial infection among these patients was alarmingly high at $51.1 \%(92 / 180)$. Of the 92 chlamydia-infected patients, $93.5 \%$ (86/92) were infected with plasmid-bearing (+) C. trachomatis while the remaining $6.5 \%$ (6/92) were caused by the plasmid-free (-) variant. Our data showed that genital C. trachomatis infection was associated with infertility issues, inflammation in the reproductive tract (mucopurulent cervicitis or endometriosis), irregular menstrual cycles and polycystic ovarian syndrome (PCOS). However, no statistical significance was detected among patients with plasmid (+) versus plasmid $(-)$ C. trachomatis infection. Interestingly, plasmid (+) C. trachomatis was detected in all patients with PCOS, and the plasmid copy numbers were significantly higher among PCOS patients, relative to non-PCOS patients.
\end{abstract}

Conclusion: Our findings show a high incidence of $C$. trachomatis infection among women with infertility or gynecological problems in Malaysia. However, due to the low number of plasmid $(-)$ C. trachomatis cases, a significant role of the plasmid in causing virulence in human requires further investigation of a larger cohort.

Keywords: Chlamydia trachomatis, Reproductive system disorders, Infertility, Plasmid

\footnotetext{
* Correspondence: wonfen@um.edu.my

${ }^{1}$ Department of Medical Microbiology, Tropical Infectious Disease Research and Education Center, Faculty of Medicine, University of Malaya, 50603 Kuala Lumpur, Malaysia

Full list of author information is available at the end of the article
} 


\section{Background}

Chlamydia trachomatis is a common bacterial sexually transmitted disease (STD) worldwide. Chlamydial urogenital infection has increased at a fast rate, with more than 2.8 million new cases diagnosed each year [1]. In Malaysia, a high prevalence of chlamydial antibody was detected among urban citizens [2], particularly young females and sex workers [3]. Long term asymptomatic persistency of the pathogen among 50-70\% of individuals results in wide spread of the disease [4], and leads to delayed treatment, which in turn causes prostatitis and epididymitis in males or infertility in females [5]. In females, the pathogen can ascend the reproductive tract to the endometrial epithelium and fallopian tubes, leading to pelvic inflammatory disease (PID) in approximately $20-40 \%$ of the infected patients; among which
$11 \%$ develop tubal factor infertility while $9 \%$ show ectopic pregnancy [6]. C. trachomatis-mediated inflammation in the genital tract can result in cervicitis or endometriosis, causing lesions, abnormal mucopurulent discharge and thickening of the uterus inner layer [6]. Inflammation can also contribute to hormonal disorders, i.e., polycystic ovarian syndrome (PCOS) and irregular menses [7]. Additionally, newborn infants can be infected at birth when delivered through an infected birth canal, causing severe conjunctivitis or pneumonia [8].

In recent years, several research groups suggest that the $C$. trachomatis without plasmid demonstrates a weaker degree of virulence. The plasmid-deficient strains show impaired ability to infect the female mouse genital tract $[9,10]$. C. trachomatis infection damages the reproductive tract by activating TLR2 and initiates a Th1-

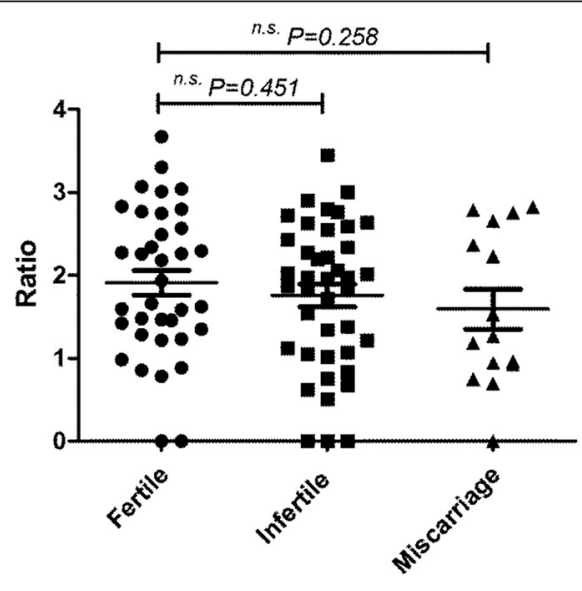

Fertility

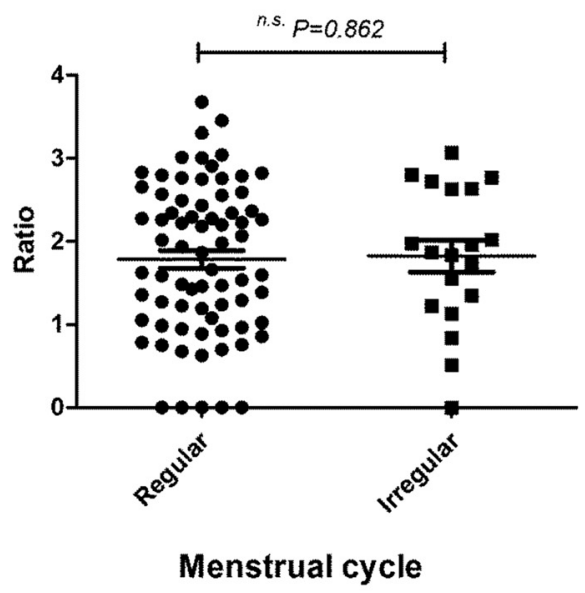

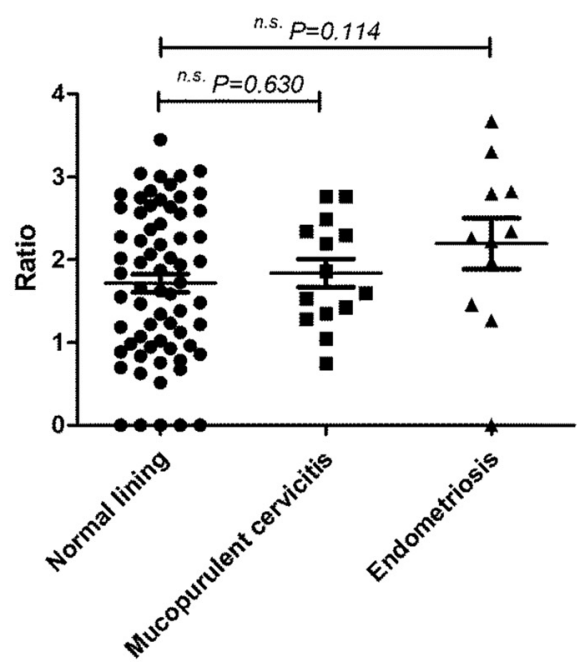

Reproductive system

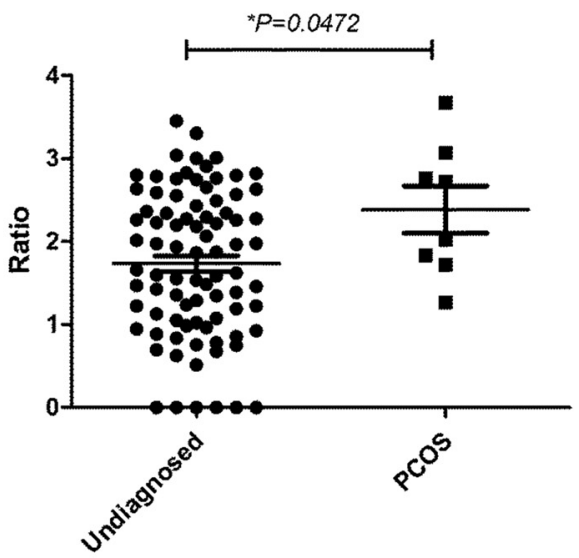

Hormonal disorder

Fig. 1 Plasmid copy numbers among C. trachomatis-infected patients with different clinical parameters. Dot plot graphs show the ratio of plasmid:Momp as determined by quantitative real-time PCR assay. Each dot represents data from a single patient in each group $(n=92)$. The $P$ values were measured with unpaired Student's $t$-test. Data was considered significant when ${ }^{*} P<0.05$. n.s.: non-significant 
dependent inflammatory response. In a study using plasmid-cured C. muridarum mutant infection in a murine model, TLR2-dependent cytokine was not detected and no sign of oviduct damage can be observed, suggesting that the plasmid-cured mutant has lost virulence [9]. Also, intra-vaginal immunization of the plasmiddeficient strains provide protection in the murine model of genitourinary tract infection [11]; as well as in trachoma infected macaques [12] due to the failure to trigger a Toll-like receptor 2-dependent immune response [13]. These findings have led to research on use of plasmiddeficient strains as a potential human vaccine. In fact, an intravaginal infection of attenuated plasmidless C. trachomatis L2 has been shown to provide protection to the host because it is nonpathogenic and raises systemic antibody in the $\mathrm{C} 3 \mathrm{H} / \mathrm{HeJ}$ mouse model [11].

Despite compelling evidence in animal models, there is no equivalent finding from human clinical study confirming the significance of plasmid in C. trachomatis infection. A recent study in human ocular C. trachomatis infection reveals that no direct association exists between plasmid copy numbers and disease severity [14]. Therefore, further work should be done to establish the plausible connection. In this study, we investigated the prevalence of plasmid-bearing (+) or plasmid-free (-) C. trachomatis infection and the plasmid copy numbers among obstetrics and gynecology patients in Kuala Lumpur, the capital city of Malaysia. By associating the data with the patients' clinical presentations, we evaluated the prevalence and risk of plasmid (+) and plasmid (-) variants in affecting gynecological disorders.

\section{Results}

\section{Demographics of the study population}

The patient cohort from this study comprised 180 female patients of child-bearing age (mean: 30.95 years old; IQR: 27-35) who visited the Obstetrics and Gynecology clinic at the University of Malaya Medical Centerfrom 2010 to 2014 (Table 1). A total number of 124 patients were married, 13 were single or had divorced, and the remaining 43 patients did not reveal their marital status. Most of the patients were of Malay ethnicity (68.3\%), followed by Indians (13.3\%), Chinese $(12.7 \%)$, and others (5.5\%), reflecting the demographics of the multiethnic Malaysian population. A majority of the patients recruited to the study presented with gynecological complications or subfertility issues, and had a higher risk of STD infection. The main reason for

Table 1 Patient demographics. Numbers (percentages) of patients with or without C. trachomatis infection; and patients infected with plasmid ( $(-)$ or plasmid (+) variants. $n=180$. The $P$ values for all variables were measured with Fisher's exact test. For age, a $t$-test $\left({ }^{a}\right)$ was used. n.s.: non-significant

\begin{tabular}{|c|c|c|c|c|c|c|c|c|c|}
\hline Parameters & $\begin{array}{l}\text { All patients } \\
(n=180)\end{array}$ & $\begin{array}{l}\text { No infection } \\
(n=88)\end{array}$ & $\begin{array}{l}\text { C. trachomatis } \\
\text { infection }(n=92)\end{array}$ & $P$ value & OR(95 \% Cl) & $\begin{array}{l}\text { Plasmid }(-) \\
\text { C. trachomatis } \\
(n=6)\end{array}$ & $\begin{array}{l}\text { Plasmid }(+) \\
\text { C. trachomatis } \\
(n=86)\end{array}$ & $P$ value & OR(95\% Cl) \\
\hline \multicolumn{10}{|l|}{ Age (years) } \\
\hline Mean $[\mathrm{IQR}]$ & $\begin{array}{l}30.9 \\
{[27-35]}\end{array}$ & $\begin{array}{l}30.7 \\
{[27-34.25]}\end{array}$ & $\begin{array}{l}31.29 \\
{[27-35]}\end{array}$ & $0.60^{\text {n.s. a }}$ & & $\begin{array}{l}30.2 \\
{[26.75-32.25]}\end{array}$ & $\begin{array}{l}33.3 \\
{[27-35]}\end{array}$ & $0.59^{\text {n.s. a }}$ & \\
\hline Maximum & 45 & 44 & 45 & & & 36 & 45 & & \\
\hline Minimum & 20 & 20 & 20 & & & 26 & 20 & & \\
\hline \multicolumn{10}{|l|}{ Marital status } \\
\hline Married & $\begin{array}{l}124 \\
(68.8 \%)\end{array}$ & $\begin{array}{l}55 \\
(44.4 \%)\end{array}$ & $\begin{array}{l}69 \\
(55.6 \%)\end{array}$ & $0.078^{\text {n.s. }}$ & $\begin{array}{l}1.800 \\
(0.94-3.41)\end{array}$ & $\begin{array}{l}3 \\
(4.3 \%)\end{array}$ & $\begin{array}{l}66 \\
(95.6 \%)\end{array}$ & $0.16^{\text {n.s. }}$ & $\begin{array}{l}0.303 \\
(0.056-1.62)\end{array}$ \\
\hline Single & $\begin{array}{l}12 \\
(6.7 \%)\end{array}$ & $\begin{array}{l}6 \\
(50 \%)\end{array}$ & $\begin{array}{l}6 \\
(50 \%)\end{array}$ & $1.00^{\text {n.s. }}$ & $\begin{array}{l}0.953 \\
(0.29-3.07)\end{array}$ & $\begin{array}{l}0 \\
(0 \%)\end{array}$ & $\begin{array}{l}6 \\
(100 \%)\end{array}$ & $1.00^{\text {n.s. }}$ & $\begin{array}{l}0.952 \\
(0.048-18.87)\end{array}$ \\
\hline Divorced & $\begin{array}{l}1 \\
(0.5 \%)\end{array}$ & $\begin{array}{l}0 \\
(0 \%)\end{array}$ & $\begin{array}{l}1 \\
(100 \%)\end{array}$ & $1.00^{\text {n.s. }}$ & $\begin{array}{l}2.902 \\
(0.11-72.24)\end{array}$ & $\begin{array}{l}0 \\
(0 \%)\end{array}$ & $\begin{array}{l}1 \\
(100 \%)\end{array}$ & $1.00^{\text {n.s. }}$ & $\begin{array}{l}4.385 \\
(0.16-118.8)\end{array}$ \\
\hline unknown & $\begin{array}{l}43 \\
(23.8 \%)\end{array}$ & $\begin{array}{l}27 \\
(62.7 \%)\end{array}$ & $\begin{array}{l}16 \\
(37.3 \%)\end{array}$ & $0.053^{\text {n.s. }}$ & $\begin{array}{l}0.475 \\
(0.23-0.96)\end{array}$ & $\begin{array}{l}3 \\
(18.7 \%)\end{array}$ & $\begin{array}{l}13 \\
(81.2 \%)\end{array}$ & $0.60^{\text {n.s. }}$ & $\begin{array}{l}5.615 \\
(1.02-3.09)\end{array}$ \\
\hline \multicolumn{10}{|l|}{ Ethnicity } \\
\hline Malay & $\begin{array}{l}123 \\
(68.3 \%)\end{array}$ & $\begin{array}{l}64 \\
(52.1 \%)\end{array}$ & $\begin{array}{l}59 \\
(47.9 \%)\end{array}$ & $0.26^{\text {n.s. }}$ & $\begin{array}{l}0.6705 \\
(0.35-1.26)\end{array}$ & $\begin{array}{l}4 \\
(6.7 \%)\end{array}$ & $\begin{array}{l}55 \\
(93.2 \%)\end{array}$ & $1.00^{\text {n.s. }}$ & $\begin{array}{l}1.127 \\
(0.19-6.51)\end{array}$ \\
\hline Indian & $\begin{array}{l}24 \\
(13.3 \%)\end{array}$ & $\begin{array}{l}11 \\
(45.9 \%)\end{array}$ & $\begin{array}{l}13 \\
(54.1 \%)\end{array}$ & $0.82^{\text {n.s. }}$ & $\begin{array}{l}1.152 \\
(0.48-2.72)\end{array}$ & $\begin{array}{l}1 \\
(7.6 \%)\end{array}$ & $\begin{array}{l}12 \\
(92.3 \%)\end{array}$ & $1.00^{\text {n.s. }}$ & $\begin{array}{l}1.233 \\
(0.13-11.50)\end{array}$ \\
\hline Chinese & $\begin{array}{l}23 \\
(12.7 \%)\end{array}$ & $\begin{array}{l}10 \\
(43.5 \%)\end{array}$ & $\begin{array}{l}13 \\
(56.5 \%)\end{array}$ & $0.65^{\text {n.s. }}$ & $\begin{array}{l}1.284 \\
(0.53-3.10)\end{array}$ & $\begin{array}{l}1 \\
(7.6 \%)\end{array}$ & $\begin{array}{l}12 \\
(92.3 \%)\end{array}$ & $1.00^{\text {n.s. }}$ & $\begin{array}{l}1.233 \\
(0.13-11.50)\end{array}$ \\
\hline Others & $\begin{array}{l}10 \\
(5.5 \%)\end{array}$ & $\begin{array}{l}3 \\
(30 \%)\end{array}$ & $\begin{array}{l}7 \\
(70 \%)\end{array}$ & $0.33^{\text {n.s. }}$ & $\begin{array}{l}2.333 \\
\text { (0.58 to } 9.32 \text { ) }\end{array}$ & $\begin{array}{l}0 \\
(0.0 \%)\end{array}$ & $\begin{array}{l}7 \\
(100.0 \%)\end{array}$ & $1.00^{\text {n.s. }}$ & $\begin{array}{l}0.815 \\
(0.13-11.50)\end{array}$ \\
\hline
\end{tabular}


patients' visit to the clinic was due to infertility (37\%). Other reasons included abdominal pain, bleeding, menorrhagia, irregular menstrual cycles and others. Two patients had cystectomy whereas one had a history of resolved PID.

\section{C. trachomatis infection is associated with various gynecological disorders}

Genital C. trachomatis infection in each patient was first diagnosed by detection of the $C$. trachomatis Momp (OmpA) gene. Total DNA was first isolated from the patients' endocervical swabs and PCR amplified using a human $\beta$-globin control primer to ensure the successful extraction of DNA from the endocervical swabs (data not shown). The presence of C. trachomatis DNA was detected with Momp primer using a nested PCR amplification method (outer primers followed by inner primer amplification) [15]. The results were further confirmed using a quantitative realtime PCR method with inner primer alone. MOMP is expressed on the cell surface with a porin activity that is often used for diagnosis of $C$. trachomatis [16]. Over half of the patients, i.e., $51.1 \%(92 / 180)$, were diagnosed with genital $C$. trachomatis infection, suggesting a high incidence of sexually transmitted chlamydial infection among the female patients recruited (Table 2). No significant difference was detected among patients by age, marital status or ethnic background. We then sequenced the Momp PCR product and performed a nucleotide BLAST to assess the diversity of $C$. trachomatis strains in the local population. Interestingly, our data revealed that all samples examined showed a D serotype (data not shown).

Overall, C. trachomatis infection showed an association with infertility (OR:9.85, $95 \%$ CI:4.70-20.63, $P<$ $0.0001^{* m a k}$ ) (Table 2). Among patients who were fertile, only $32.1 \%(36 / 112)$ were infected by C. trachomatis, whereas among infertile patients, $82.4 \%(56 / 68)$ had $C$. trachomatis infection. Notably, a high C. trachomatis prevalence of $90.7 \%(39 / 43$,) was detected among patients who were diagnosed with primary $\left(1^{\circ}\right)$ or secondary $\left(2^{\circ}\right)$ infertility (OR:20.580, $95 \%$ CI:6.83-62.02, $P<$ $\left.0.0001^{\mathrm{mos}}\right)$. Meanwhile, $68 \%(17 / 25)$ of patients who experienced miscarriage were infected by $C$. trachomatis (OR:4.486, 95 \% CI:1.77-11.36, $P=0.0013^{\text {*tit }}$ ).

The inflammation (cervicitis with mucopurulent discharge or endometriosis) of patients' reproductive tract was recorded by clinicians during examination. C. trachomatis infection showed a close connection with the inflammation in the reproductive system (OR:3.84, $95 \%$ CI:1.69-8.72, $P=0.0008^{* * * * *}$ ) (Table 2). Our data showed that approximately $64 \%(16 / 25)$ of patients who were diagnosed with mucopurulent cervicitis (OR:2.167, $95 \%$ CI:0.90-5.23, $P=0.087)$ and $100 \%(12 / 12)$ of patients with endometriosis (OR:30.43, 95 \% CI:1.77-524.2, $P<$ $0.0001^{* * m *}$ ) had C. trachomatis infection.

In addition, we showed that $C$. trachomatis infection exhibited significant association with irregular menstrual cycles (OR:2.07, $95 \%$ CI:1.05-4.06, $\left.P=0.045^{\prime \prime}\right)$ as well as PCOS (OR:9.43, $95 \%$ CI:1.17-76.14, $P=0.018^{*}$ ), when compared to the uninfected controls.

Table 2 Chlamydial infection in patients with different symptoms. Numbers (percentages) of patients with or without C. trachomatis infection. $n=180$. The $P$ values for all variables were measured with Fisher's exact test. $n$.s.: non-significant

\begin{tabular}{|c|c|c|c|c|c|}
\hline Parameters & All patients $(n=180)$ & Non-infected $(n=88)$ & C. trachomatis-infected $(n=92)$ & $P$ value & Odd Ratio (95% Cl) \\
\hline \multicolumn{6}{|l|}{ Fertility } \\
\hline Fertile & 112 & $76(67.9 \%)$ & $36(32.1 \%)$ & & \\
\hline Infertile & 68 & $12(17.6 \%)$ & $56(82.4 \%)$ & $<0.0001^{* * *}$ & 9.852 (4.70 to 20.63 ) \\
\hline$-1^{\circ}$ or $2^{\circ}$ infertility & 43 & $4(9.3 \%)$ & 39 (90.7 \%) & $<0.0001^{* * *}$ & 20.580 (6.83 to 62.02$)$ \\
\hline - Miscarriage & 25 & $8(32.0 \%)$ & $17(68.0 \%)$ & $0.0013^{* *}$ & 4.486 (1.77 to 11.36$)$ \\
\hline \multicolumn{6}{|l|}{ Reproductive tract } \\
\hline Normal lining & 143 & $79(55.2 \%)$ & $64(44.8 \%)$ & & \\
\hline Inflammation & 37 & $9(24.3 \%)$ & 28 (75.7 \%) & $0.00088^{* * *}$ & 3.84 (1.69 to 8.72 ) \\
\hline - Mucopurulent Cervicitis & 25 & $9(36.0 \%)$ & $16(64.0 \%)$ & $0.0876^{\text {n.s. }}$ & 2.167 (0.90 to 5.23$)$ \\
\hline - Endometriosis & 12 & $0(0.0 \%)$ & $12(100.0 \%)$ & $0.0001^{* * *}$ & 30.43 (1.77 to 524.2$)$ \\
\hline \multicolumn{6}{|l|}{ Menstrual Cycle } \\
\hline Regular & 130 & $70(53.8 \%)$ & 60 (46.2 \%) & & \\
\hline Irregular & 50 & $18(36.0 \%)$ & $32(64.0 \%)$ & $0.0452^{*}$ & 2.074 (1.05 to 4.06$)$ \\
\hline \multicolumn{6}{|l|}{ Hormonal Disorder } \\
\hline Undiagnosed & 170 & $87(51.2 \%)$ & $83(48.8 \%)$ & & \\
\hline PCOS & 10 & $1(10.0 \%)$ & 9 (90.0 \%) & $0.0184^{*}$ & 9.434 (1.17 to 76.14$)$ \\
\hline
\end{tabular}

${ }^{*} P<0.05{ }^{*} P<0.01{ }^{* *} P<0.001$ 


\section{Higher incidence of plasmid-bearing C. trachomatis infection among patients with infertility, inflammation and PCOS}

Next, we investigated if the patients enrolled were infected by plasmid (+) or (-) C. trachomatis variants. Total DNA extracted from the vaginal swabs of the $C$. trachomatis-infected patients were amplified with two sets of cryptic plasmid primers (which target Pgp1 and Pgp8 respectively) using quantitative real-time PCR analysis. Of the 92 C. trachomatis-infected patients, we detected that $93.5 \%(86 / 92)$ were caused by plasmid (+) C. trachomatis whereas only $6.5 \%(6 / 92)$ were caused by plasmid (-) C. trachomatis (Table 1).

When comparing the clinical parameters of the patients, we noted no significant correlation between the plasmid and the tendency for the patients to exhibit infertility (OR:0.76, $95 \%$ CI:0.13-4.40, $P=0.562$ ), inflammation (OR:5.26, $95 \%$ CI:0.28-98.68, $P=0.155$ ), irregular menses (OR:2.81, $95 \%$ CI:0.31-25.24, $P=$ 0.315 ) and PCOS (OR:1.59, $95 \%$ CI:0.08-30.6, $P=$ 0.529) (Table 3). Among the patients with infertility, $92.8 \%(52 / 56)$ cases were diagnosed with plasmid (+) C. trachomatis, compared to only $7.14 \%(4 / 56)$ cases with plasmid (-) C. trachomatis. Similarly, the majority of the patients who had inflammation in the reproductive tract $(96.4 \%, 27 / 28)$ and PCOS $(100 \%, 9 / 9)$ were caused by plasmid $(+)$ C. trachomatis. Among the 6 patients infected by plasmid (-) C. trachomatis, 2 were fertile while 4 had infertility. However, 5 among the 6 showed no sign of inflammation and had regular menstrual cycles.

\section{Higher relative plasmid copy numbers associated with PCOS}

To examine if the abundance of plasmid in C. trachomatis is associated with the presence of the clinical symptoms, we quantified the plasmid copy numbers in each patient (Figure 1). The average $C_{T}$ value from two cryptic plasmid primers (Pgp1 and Pgp8) for each patient was obtained. Relative plasmid copy numbers per bacterium (ratio for plasmid:Momp) for all 92 C. trachomatisinfected patients were calculated. In general, we noticed no direct connection between fertility, the reproductive tract lining and menstrual cycle, consistent with the previous studies in human ocular infection and in vitro tissue tropism [14, 17]. Notably, PCOS patients showed a higher plasmid copy number $(2.386 \pm 0.284$ versus 1.734 $\pm 0.096, P=0.0472$ ), relative to the non-PCOS patients. Although endometriosis patients also demonstrated a

Table 3 C. trachomatis plasmid in patients with different symptoms. Numbers (percentages) of patients infected with plasmid (-) or plasmid (+) C. trachomatis variants. $n=92$. The $P$ values for all variables were measured with Fisher's exact test. $n$.s.: non-significant

\begin{tabular}{|c|c|c|c|c|c|}
\hline Parameters & $\begin{array}{l}\text { C. trachomatis-infected } \\
\text { patients }(n=92)\end{array}$ & $\begin{array}{l}\text { Plasmid }(-) \\
\text { C. trachomatis }(n=6)\end{array}$ & $\begin{array}{l}\text { Plasmid }(+) \\
\text { C. trachomatis }(n=86)\end{array}$ & $P$ value & $\begin{array}{l}\text { Odd Ratio } \\
\text { (95\% Cl) }\end{array}$ \\
\hline \multicolumn{6}{|l|}{ Fertility } \\
\hline Fertile & 36 & $2(5.55 \%)$ & 34 (94.4 \%) & & \\
\hline Infertile & 56 & $4(7.14 \%)$ & $52(92.8 \%)$ & $0.5629^{\text {n.s. }}$ & $\begin{array}{l}0.764 \\
(0.13 \text { to } 4.40)\end{array}$ \\
\hline$-1^{\circ}$ or $2^{\circ}$ infertility & 39 & $3(7.6 \%)$ & 36 (92.3\%) & $0.5295^{\text {n.s. }}$ & $\begin{array}{l}0.755 \\
(0.14 \text { to } 3.95)\end{array}$ \\
\hline - Miscarriage & 17 & $1(5.8 \%)$ & 16 (88.2 \%) & $0.6939^{\text {n.s. }}$ & $\begin{array}{l}0.875 \\
\text { (0.09 to } 8.01)\end{array}$ \\
\hline \multicolumn{6}{|l|}{ Reproductive tract } \\
\hline Normal lining & 64 & $5(7.8 \%)$ & 59 (92.1\%) & & \\
\hline Inflammation & 28 & $1(3.5 \%)$ & 27 (96.4 \%) & $0.4045^{\text {n.s. }}$ & $\begin{array}{l}2.288 \\
(0.25 \text { to } 20.55)\end{array}$ \\
\hline - Mucopurulent Cervicitis & 16 & $0(0.0 \%)$ & $16(100 \%)$ & $0.1550^{\text {n.s. }}$ & $\begin{array}{l}5.269 \\
(0.28 \text { to } 98.68)\end{array}$ \\
\hline - Endometriosis & 12 & $1(8.3 \%)$ & $11(91.6 \%)$ & $0.5786^{\text {n.s. }}$ & $\begin{array}{l}0.733 \\
\text { (0.078 to } 6.88)\end{array}$ \\
\hline \multicolumn{6}{|l|}{ Menstrual Cycle } \\
\hline Regular & 60 & $5(8.3 \%)$ & 55 (91.6\%) & & \\
\hline Irregular & 32 & 1 (3.1\%) & 31 (96.8\%) & $0.3153^{\text {n.s. }}$ & $\begin{array}{l}2.818 \\
(0.31 \text { to } 25.24)\end{array}$ \\
\hline \multicolumn{6}{|l|}{ Hormonal Disorder } \\
\hline Undiagnosed & 83 & $6(72.2 \%)$ & 77 (92.7 \%) & & \\
\hline PCOS & 9 & $0(0 \%)$ & $9(100 \%)$ & $0.5293^{\text {n.s. }}$ & $\begin{array}{l}1.59 \\
(0.083 \text { to } 30.6)\end{array}$ \\
\hline
\end{tabular}


comparatively higher plasmid copy number, (2.193 \pm 0.308 versus $1.714 \pm 0.110, P=0.114)$, no statistical significance was noted.

\section{Discussion}

In this study, we reported a high prevalence $(51.1 \%)$ of C. trachomatis infection among female adults of child bearing age, with subfertility or gynecological problems who visited Obstetrics and Gynecology clinics in Malaysia. This indicates that there is a pressing need for wider population screening to increase awareness and prevent the spread of the disease among the community. Most of the patients who demonstrated symptoms were diagnosed with genital C. trachomatis infection, including infertility $(82.4 \%)$, reproductive system lesions (75.7\%), irregular menses (64\%) and PCOS (90\%), suggesting the $C$. trachomatis is a leading factor for female reproductive system disorders.

Although a high rate of genital C. trachomatis prevalance was detected in our study, the patients recruited were suspected to be at risk of the bacterial infection based on the clinical examination. The rates of $C$. trachomatis infection vary in different studies depending on the group of patients recruited and the study region. For example, a study using 50 infertile female patients showed a $40 \%$ infection rate by $C$. trachomatis [18] whereas other studies reported only a $8 \%$ [19] or $15 \%$ C. trachomatis infection rate. Among patients with tubal infertility, the prevalence of C. trachomatis was reported to be $38.3 \%$ among 120 patients [20]. Consistent to the previous study, the presence of plasmid (+) C. trachomatis was high (93.5\%). However, the prevalence using real-time PCR amplification depends highly on the assay sensitivity. For data validation, a glycogen-positive test for bacterial isolates can be used to confirm the presence of plasmid in the bacteria [21].

Various research groups have established that the plasmid (+) C. trachomatis demonstrated a higher virulence in animal models of ocular or genital infections [9-14]. Consistent with these findings, our results showed that high percentages of those who had infertility (92.8\%), inflammation in the reproductive tract $(96.4 \%)$, irregular menses $(96.8 \%)$ and PCOS (100\%) were diagnosed with plasmid (+) but not plasmid (-) variants of C. trachomatis. Although these observations provide support for previous work which suggests the usage of plasmidless $C$. trachomatis as a potential human vaccine [11], caution must be taken as some of the patients who showed symptoms were infected by the plasmid (-) strains. Also note that the genetic diversity of human populations may contribute to results contradicting experiments performed using inbred animals. Therefore, additional surveys which involve a larger human cohort should be conducted to ensure the over-all safety of the plasmidless strains among individuals from diverse backgrounds.

Plasmid (+) or (-) C. trachomatis strains demonstrated no difference with regards to growth kinetics, plaquing efficiency and size but showed a defect in glycogen granule accumulation and intrainclusion movement [10]. A recent study showed that $C$. trachomatis is capable of inducing alteration to global host histone modifications and double strand break repair, thus generating an environment favorable for malignant transformation [22]. In fact, $C$. trachomatis infection poses risk for infected individuals to develop cervix intraepithelial neoplasia $[23,24]$, in a similar way to other tumor-inducing pathogens. Extra-chromosomal plasmid DNA may play a role in integrating with the host genome which leads to this pathological damage. The conserved $7.5 \mathrm{~kb}$ cryptic plasmid is a small, non-conjugative and non-integrative extrachromosomal DNA that contains genes encoding 8 proteins [25]. The plasmid Pgp3 encodes for immunogenic trimers which trigger specific antibody production in infected individuals [26, 27]; and is secreted into the cytosol of infected cells during chlamydial infection [28, 29]. Meanwhile, Pgp4 encodes for a protein which comprises a putative helix-loop-helix domain which functions as transcriptional regulator for virulence-associated genes [10, 30]. Therefore, expression of plasmid genes may be crucial in leading to clinical symptoms. To support this notion, a quantitative protein analysis could be carried out in the future to measure the amount of plasmid-derived proteins in the patient sample.

\section{Conclusion}

In conclusion, we suggest that plasmids maybe a potential risk factor for reproductive system disorders including infertility, inflammation in the reproductive tract, irregular menses and PCOS in genital chlamydial infection. However, continued work is required to substantiate plasmids as a virulence factor in future studies with a larger human cohort.

\section{Methods \\ Study design}

A total number of 180 female patients of child-bearing age who visited the Obstetrics and Gynecology Outpatient Clinics at the University of Malaya Medical Centre voluntarily participated in the study from 2010 to 2014. Detailed clinical information on reasons for referral, gynecological history including menstruation, symptoms of genital and urinary tract infection, obstetric and medical histories were documented. The subjects' vulva and cervix were examined for the presence of lesions, warts, ulcers, ectopy, erythma and discharge. Patients with a positive urine pregnancy test, recent antibiotic therapy, yeast infection and genital tuberculosis 
were excluded from the study. The participants were briefed that their blood and vaginal swab samples will be used for research purposes, and written consent was obtained. This study has been approved by the University of Malaya Medical Centre Medical Ethics Committee.

\section{DNA extraction}

Endocervical swabs were collected by using a Floqswab (Copan, Brescia, Italy) and transferred to a laboratory in a UTM-RT universal transport medium tube (Copan). The samples were vortex mixed and the cells were centrifuged at $400 \times \mathrm{g}$ for $10 \mathrm{~min}$. The cells recovered were lysed and separated with phenol chloroform. The DNA was precipitated using 1:10 volume of $3 \mathrm{M}$ sodium acetate and isopropanol at $-20{ }^{\circ} \mathrm{C}$ overnight incubation. The samples were washed and eluted with TE buffer.

\section{PCR amplification}

Diagnosis of C. trachomatis was performed as described [15]. Nested PCR was performed to amplify the genes that encode for Major Outer Membrane Protein (MOMP) and plasmid using outer and inner primers (Table 4). PCR samples were run in a Veriti Thermal Cycler (Applied Biosystems, Essex, UK) at the following conditions: $95{ }^{\circ} \mathrm{C}$ for $3 \mathrm{~min}, 30$ cycles of $95{ }^{\circ} \mathrm{C}$ for $30 \mathrm{~s}$, $50{ }^{\circ} \mathrm{C}$ for $1 \mathrm{~min}$, and $72{ }^{\circ} \mathrm{C}$ for $1 \mathrm{~min}$, followed by a final extension at $72{ }^{\circ} \mathrm{C}$ for 7 min using HelixAmp Taq DNA polymerase (Nanohelix, Daejeon, South Korea). The first round PCR was amplified using $50 \mathrm{ng}$ of DNA isolated from endocervical swabs with outer primer pairs. Then, $1 \mu \mathrm{l}$ of first round PCR product was used as the template in the second round PCR and amplified with inner primer pairs. The amplicons were run on gel electrophoresis using $1.5 \%$ agarose gel and viewed under a UV transilluminator. Human $\beta$-globin gene was used as a positive control to confirm successful DNA retrieval from patient swabs. PCR amplification for human $\beta$ globin primer was run separately in PCR master mix containing a total volume $50 \mu \mathrm{l}$ as follows: $1 \mu \mathrm{l}$ template DNA, $200 \mathrm{mM}$ of each of dNTP, 25 pmol of each primer, $4 \mathrm{mM}$ Tune Up solution, $5 \mu \mathrm{l}$ of PCR buffer and 2.5 units of HelixAmp Taq DNA polymerase recombinant (Nanohelix, Daejeon, South Korea). PCR samples were run at the following conditions: $95{ }^{\circ} \mathrm{C}$ for $3 \mathrm{~min}$, 30 cycles amplification consisted of $95{ }^{\circ} \mathrm{C}$ for $30 \mathrm{~s}, 50{ }^{\circ} \mathrm{C}$ for $1 \mathrm{~min}$, and extension at $72{ }^{\circ} \mathrm{C}$ for $1 \mathrm{~min}$, followed by final extension at $72{ }^{\circ} \mathrm{C}$ for $7 \mathrm{~min}$.

\section{Quantitative real-time PCR amplification}

A quantitative real-time PCR assay was used to confirm the diagnosis and to determine the plasmid copy numbers in patient samples. DNA samples isolated from the vaginal swabs of $C$. trachomatis-infected patients were prepared. Mastermix containing $1 \mu$ template DNA, $1 \times$ SsoAdvanced Universal SYBR Green Supermix (Biorad, Hercules, CA), 10 pmol primers were run using a Mx3000 Stratagene thermacycler (Agilent Technologies, Santa Clara, CA). Primers used were inner primers for Momp, inner primer for plasmid Pgp8, and plasmid Pgp1 primers. Plasmid copy number for each patient was calculated as below:

$$
\text { Plasmid copynumber }=\frac{\text { Average }\left(C_{T} \operatorname{Pgp} 1+C_{T} \operatorname{Pgp} 8\right)}{C_{T} M O M P}
$$

\section{Sequencing}

Amplification of an approximately $871 \mathrm{bp}$ fragment of OmpA was performed by nested PCR. The first PCR step

Table 4 PCR primers used in C. trachomatis conventional PCR and real-time PCR diagnosis. For nested PCR amplification of Momp and plasmid, outer primer pairs were used at first round PCR, while inner primer pairs were used at second round PCR amplification. For real-time PCR diagnosis, Momp inner primer pairs, plasmid Pgp8 inner primer pairs and plasmid Pgp1 primer pairs were used

\begin{tabular}{|c|c|c|c|}
\hline Target genes & Primer & Sequence $\left(5^{\prime}-3^{\prime}\right)$ & Amplicon size \\
\hline \multirow[t]{4}{*}{$\overline{M o m p}$} & Outer forward & TTGTTTCGACCGTGTTTTG & $455 \mathrm{bp}$ \\
\hline & Outer reverse & AGCRTATTGGAAAGAAGCBCCTAA & \\
\hline & Inner forward & AAACWGATGTGAATAAAGARTT & $395 \mathrm{bp}$ \\
\hline & Inner reverse & TCCCASARAGCTGCDCGAGC & \\
\hline \multirow[t]{4}{*}{ Plasmid Pgp8 } & Outer forward & TTGGCYGCTAGAAAAGGCGATT & $212 \mathrm{bp}$ \\
\hline & Outer reverse & TCCGGAACAYATGATGCGAAGT & \\
\hline & Inner forward & AACCAAGGTCGATGTGATAG & $150 \mathrm{bp}$ \\
\hline & Inner reverse & TCAGATAATTGGCGATTCTT & \\
\hline \multirow[t]{2}{*}{ Plasmid Pgp1 } & Forward & TTCTITGATGGCTTCCCAAC & $456 \mathrm{bp}$ \\
\hline & Reverse & ACGATTTTCTCCAACCGATG & \\
\hline \multirow[t]{2}{*}{$\beta$-globin } & Forward & GAAGAGCCAAGGACAGGTAC & $268 \mathrm{bp}$ \\
\hline & Reverse & CAACTTCATCCACGTTCACC & \\
\hline
\end{tabular}


was carried out with outer primer pair (Table 1) using $10 \mu \mathrm{l}$ of DNA extracted from swabs. Amplification was performed in a final reaction volume of $50 \mu \mathrm{l}$ containing $0.3 \mu \mathrm{M}$ of each primer, $0.2 \mathrm{mM}$ of dNTPs, $3 \mu \mathrm{l}$ of TuneUp solution (Nanohelix, Korea) and $5 \mathrm{U}$ of HelixAmp $^{\text {Tw } T a q ~ D N A ~ p o l y m e r a s e ~(N a n o h e l i x, ~ K o r e a) . ~ T h e ~}$ first amplification conditions consisted of initial polymerase activation at $94{ }^{\circ} \mathrm{C}$ for $2 \mathrm{~min} ; 40$ cycles of $94{ }^{\circ} \mathrm{C}$ for $45 \mathrm{~s}, 60{ }^{\circ} \mathrm{C}$ for $45 \mathrm{~s}$ and $72{ }^{\circ} \mathrm{C}$ for $90 \mathrm{~s}$ and a final elongation step at $72{ }^{\circ} \mathrm{C}$ for $5 \mathrm{~min}$. In the second round PCR, $3 \mu \mathrm{l}$ of product from the first PCR step was amplified using inner primer pairs (Table 1). Nested PCR conditions consisted of $95{ }^{\circ} \mathrm{C}$ for $5 \mathrm{~min}$; 40 cycles of $94{ }^{\circ} \mathrm{C}$ for $1 \mathrm{~min}, 60{ }^{\circ} \mathrm{C}$ for $1 \mathrm{~min}$ and $72{ }^{\circ} \mathrm{C}$ for $2 \mathrm{~min}$ and a final elongation step at $72{ }^{\circ} \mathrm{C}$ for $10 \mathrm{~min}$. The amplified products were visualized by electrophoresis on $1.5 \%$ agarose gel stained with GelRed solution (Biotium).

The $871 \mathrm{bp}$ OmpA fragments obtained were purified using a QIAquick Gel Extraction kit (Qiagen) and processed using a BigDye ${ }^{\bullet}$ Terminator v3.1 Cycle Sequencing Kit (Applied Biosystems, Foster City, CA). The reaction mixtures were loaded onto a 3730xL DNA Analyzers (Applied Biosystems). The primers used for sequencing were inner primer pairs. Nucleotide sequence data were assembled by Bioedit and residues corresponding to flanking primers were excluded from analysis. Sequences were submitted to the standard nucleotide BLAST search engine at the National Center for Biotechnology Information (blast.ncbi.nlm.nih.gov/Blast.cgi) to determine the genotype.

\section{Statistical analysis}

Statistical analysis was done using GraphPad PRISM version 5. For normally distributed data, an unpaired $t$-test was used. For categorical data (clinical symptoms), Fisher's exact test was used, with a no-symptom group as control. Odd ratio (OR) and $95 \%$ confidence interval (CI) were calculated. Statistical significance was determined at $P<0.05^{* \prime}, P<0.01^{* * *}$ and $P<0.001^{* m *}$.

\section{Availability of data and materials}

All data and materials are available upon request.

\begin{abstract}
Abbreviations
MOMP: Major outer membrane protein; OD: optical density; PCOS: polycystic ovary syndrome; PID: pelvic inflammatory disease; STD: sexually transmitted disease.
\end{abstract}

\section{Competing interests}

The authors declare that they have no competing interests.

\section{Authors' contributions}

NSS, EMS, BPA, RG and SAB designed and supervised the study. TCY, FS, GMYT, and EM performed the experiments. SS and JH collected the samples and recorded clinical parameters of all patients. WFW and CYL performed statistical analysis of the study. TCY and WFW wrote the manuscript. All authors read and approved the final manuscript.

\section{Acknowledgements}

The authors would like to thank the volunteers and nurses at the University of Malaya Medical Center Obstetrics and Gynecology clinics for their assistance in sample collection. This study was supported by grants from Malaysia Ministry of Higher Education (HIR-MOHE E000013-20001) to WFW and Fundamental Research Grant Scheme (FRGS) FP027-2010B to NSS.

\section{Author details}

'Department of Medical Microbiology, Tropical Infectious Disease Research and Education Center, Faculty of Medicine, University of Malaya, 50603 Kuala Lumpur, Malaysia. ${ }^{2}$ Faculty of Medicine, SEGi University, 47810 Petaling Jaya, Malaysia. ${ }^{3}$ Department of Obstetrics and Gynecology, Faculty of medicine, University of Malaya, 50603 Kuala Lumpur, Malaysia. ${ }^{4}$ Department of Pharmacology, Faculty of Medicine, University of Malaya, 50603 Kuala Lumpur, Malaysia. ${ }^{5}$ Center of Excellence in Infection Genomics, South Texas Center For Emerging Infectious Diseases, University of Texas at San Antonio, 78249 San Antonio, TX, USA.

Received: 4 June 2015 Accepted: 10 March 2016

Published online: 18 March 2016

\section{References}

1. Weinstock H, Berman S, Cates Jr W. Sexually transmitted diseases among American youth: incidence and prevalence estimates, 2000. Perspect Sex Reprod Health. 2004;36(1):6-10

2. Ngeow YF, Rachagan SP, Ramachandran S. Prevalence of chlamydial antibody in Malaysians. J Clin Pathol. 1990;43(5):400-2.

3. Ramachandran S, Ngeow YF. The prevalence of sexually transmitted diseases among prostitutes in Malaysia. Genitourin Med. 1990;66(5):334-6.

4. Peipert JF. Clinical practice. Genital chlamydial infections. N Engl J Med. 2003;349(25):2424-30

5. Cunningham KA, Beagley KW. Male genital tract chlamydial infection: implications for pathology and infertility. Biol Reprod. 2008;79(2):180-9.

6. Cohen CR, Brunham RC. Pathogenesis of Chlamydia induced pelvic inflammatory disease. Sex Transm Infect. 1999;75(1):21-4.

7. Morin-Papunen LC, Duleba AJ, Bloigu A, Jarvelin MR, Saikku P, Pouta A. Chlamydia antibodies and self-reported symptoms of oligo-amenorrhea and hirsutism: a new etiologic factor in polycystic ovary syndrome? Fertil Steril. 2010;94(5):1799-804.

8. Mardh PA. Influence of infection with Chlamydia trachomatis on pregnancy outcome, infant health and life-long sequelae in infected offspring. Best Pract Res Clin Obstet Gynaecol. 2002;16(6):847-64.

9. O'Connell CM, Ingalls RR, Andrews Jr CW, Scurlock AM, Darville T. Plasmiddeficient Chlamydia muridarum fail to induce immune pathology and protect against oviduct disease. J Immunol. 2007;179(6):4027-34.

10. Carlson JH, Whitmire WM, Crane DD, Wicke L, Virtaneva K, Sturdevant DE, Kupko JJ, 3rd, Porcella SF, Martinez-Orengo N, Heinzen RA et al. The Chlamydia trachomatis plasmid is a transcriptional regulator of chromosomal genes and a virulence factor. Infect Immun. 2008;76(6):2273-83.

11. Olivares-Zavaleta N, Whitmire W, Gardner D, Caldwell HD. Immunization with the attenuated plasmidless Chlamydia trachomatis L2(25667R) strain provides partial protection in a murine model of female genitourinary tract infection. Vaccine. 2010;28(6):1454-62.

12. Kari L, Whitmire WM, Olivares-Zavaleta N, Goheen MM, Taylor LD, Carlson $\mathrm{JH}$, Sturdevant GL, Lu C, Bakios LE, Randall LB et al. A live-attenuated chlamydial vaccine protects against trachoma in nonhuman primates. J Exp Med. 2011;208(11):2217-23.

13. O'Connell CM, AbdelRahman YM, Green E, Darville HK, Saira K, Smith B, Darville T, Scurlock AM, Meyer CR, Belland RJ. Toll-like receptor 2 activation by Chlamydia trachomatis is plasmid dependent, and plasmid-responsive chromosomal loci are coordinately regulated in response to glucose limitation by C. trachomatis but not by C. muridarum. Infect Immun. 2011; 79(3):1044-56

14. Last AR, Roberts C, Cassama E, Nabicassa M, Molina-Gonzalez S, Burr SE, Mabey DC, Bailey RL, Holland MJ. Plasmid copy number and disease severity in naturally occurring ocular Chlamydia trachomatis infection. J Clin Microbiol. 2014;52(1):324-7.

15. Jalal H, Stephen H, Al-Suwaine A, Sonnex C, Carne C. The superiority of polymerase chain reaction over an amplified enzyme immunoassay for the detection of genital chlamydial infections. Sex Transm Infect. 2006:82(1):37-40. 
16. Sun G, Pal S, Sarcon AK, Kim S, Sugawara E, Nikaido H, Cocco MJ, Peterson EM, de la Maza LM. Structural and functional analyses of the major outer membrane protein of Chlamydia trachomatis. J Bacteriol. 2007;189(17):6222-35.

17. Ferreira R, Borges V, Nunes A, Borrego MJ, Gomes JP. Assessment of the load and transcriptional dynamics of Chlamydia trachomatis plasmid according to strains' tissue tropism. Microbiol Res. 2013;168(6):333-9.

18. Abdella RM, Abdelmoaty HI, Elsherif RH, Sayed AM, Sherif NA, Gouda HM, El Lithy A, Almohamady M, Abdelbar M, Hosni AN et al. Screening for Chlamydia trachomatis in Egyptian women with unexplained infertility, comparing real-time PCR techniques to standard serology tests: case control study. BMC Womens Health. 2015;15:45.

19. Alfarraj DA, Somily AM, Alssum RM, Abotalib ZM, El-Sayed AA, Al-Mandeel $\mathrm{HH}$. The prevalence of Chlamydia trachomatis infection among Saudi women attending the infertility clinic in Central Saudi Arabia. Saudi Med J. 2015;36(1):61-6.

20. Tukur J, Shittu SO, Abdul AM. A case control study of active genital Chlamydia trachomatis infection among patients with tubal infertility in northern Nigeria. Trop Doct. 2006;36(1):14-6.

21. Matsumoto A, Izutsu H, Miyashita N, Ohuchi M. Plaque formation by and plaque cloning of Chlamydia trachomatis biovar trachoma. J Clin Microbiol. 1998;36(10):3013-9.

22. Chumduri C, Gurumurthy RK, Zadora PK, Mi Y, Meyer TF. Chlamydia infection promotes host DNA damage and proliferation but impairs the DNA damage response. Cell Host Microbe. 2013;13(6):746-58.

23. Jensen KE, Thomsen LT, Schmiedel S, Frederiksen K, Norrild B, van den Brule A, Iftner T, Kjaer SK. Chlamydia trachomatis and risk of cervical intraepithelial neoplasia grade 3 or worse in women with persistent human papillomavirus infection: a cohort study. Sex Transm Infect. 2014;90:550-5.

24. Lehtinen M, Ault KA, Lyytikainen E, Dillner J, Garland SM, Ferris DG, Koutsky LA, Sings HL, Lu S, Haupt RM et al. Chlamydia trachomatis infection and risk of cervical intraepithelial neoplasia. Sex Transm Infect. 2011;87(5):372-6.

25. Rockey DD. Unraveling the basic biology and clinical significance of the chlamydial plasmid. J Exp Med. 2011;208(11):2159-62.

26. Comanducci M, Manetti R, Bini L, Santucci A, Pallini V, Cevenini R, Sueur JM, Orfila J, Ratti G. Humoral immune response to plasmid protein pgp3 in patients with Chlamydia trachomatis infection. Infect Immun. 1994;62(12): 5491-7.

27. Li Z, Zhong Y, Lei L, Wu Y, Wang S, Zhong G. Antibodies from women urogenitally infected with $C$. trachomatis predominantly recognized the plasmid protein pgp3 in a conformation-dependent manner. BMC Microbiol. 2008:8:90

28. Chen D, Lei L, Lu C, Galaleldeen A, Hart PJ, Zhong G. Characterization of Pgp3, a Chlamydia trachomatis plasmid-encoded immunodominant antigen. J Bacteriol. 2010;192(22):6017-24.

29. Comanducci M, Cevenini R, Moroni A, Giuliani MM, Ricci S, Scarlato V, Ratt $\mathrm{G}$. Expression of a plasmid gene of Chlamydia trachomatis encoding a novel 28 kDa antigen. J Gen Microbiol. 1993;139(5):1083-92.

30. Song L, Carlson JH, Whitmire WM, Kari L, Virtaneva K, Sturdevant DE, Watkins H, Zhou B, Sturdevant GL, Porcella SF et al. Chlamydia trachomatis plasmid-encoded Pgp4 is a transcriptional regulator of virulence-associated genes. Infect Immun. 2013;81(3):636-44

\section{Submit your next manuscript to BioMed Central and we will help you at every step:}

- We accept pre-submission inquiries

- Our selector tool helps you to find the most relevant journal

- We provide round the clock customer support

- Convenient online submission

- Thorough peer review

- Inclusion in PubMed and all major indexing services

- Maximum visibility for your research

Submit your manuscript at www.biomedcentral.com/submit

C Biomed Central 